\title{
ADMINISTRATIVE EVIDENCE
}

\author{
KEITH TURNER*
}

The last century has witnessed the rise of a new instrument of government, the administrative tribunal. In its mature form it is difficult to find its parallels in our earlier political history; its development seems indigenous. The rapidity of its growth, the significance of its powers, and the implications of its being, are such as to require notice of the extent to which this new "administrative law" is weaving itself more and more into our governmental fabric. ${ }^{1}$

In the lines which follow, I have endeavoured to set down some observations and suggestions on the subject of administrative evidence, by which I mean the factual information admitted before and acted upon by this "new instrument of government" of which Dean Landis spoke just over a quarter century ago. In doing so I have tried not to philosophize unduly, and have tried to concentrate upon the practicalities of the problemsevidentiary in nature-which face counsel engaged in proceedings before administrative agencies. There is almost no limit to the kinds of matters dealt with in such proceedings-e.g., public utilities, securities, improper trade practices, land zoning, to name but a very few. But, basically, the evidentiary problems in all these classes of proceedings do bear a similarity; a sufficient degree of similarity, at least, to warrant some common ground-rules. It is to these that I would direct attention in this article.

Perhaps in Canada the day will come when uniform administrative procedure legislation-suitable for use at the federal, provincial and local levels-will be adopted; but, until this is done, counsel engaged in proceedings before administrative agencies, whether they act as counsel to the agency itself, or for a government, or for a party or an intervenant, will have to do their best with such evidentiary concepts, standards, principles and rules as are available to them. ${ }^{2}$ Fortunately, there do exist some legislative and case-law guides which will serve to assist in the conduct of particular cases. An administrative hearing cannot be regulated quite like a civil trial. Nor can it be regulated quite like a criminal trial. Probably the best that can be done is to effect some blending and borrowing from practices and safe-guards followed in these kinds of proceedings,

- Keith Turner, LL.B., LL.M. (Man.), LL.M. (Harv.) of the Manitoba Bar. Mr. Turner has served as special counsel for the Manitoba Government in municipal land development, public utilities rate base, and Securities Act inquiries.

1 Landis, The Administrative Process 1 (1938).

2 Welch, Conduct of the Utility Rate Case 192193 (1955): "Familiarity with the conventional rules of evidence used in law courts is, of course, a necessary part of the training and equipment of every successful trial lawyer. It may be even more important for the rate case attorney. Simply because a utility rate case proceeding before a regulatory commission may dispense with strict compliance with the general rules of evidence, the rate case lawyer is not excused from thorough knowledge of the rules, as applied in court. On the contrary, the rate case lawyer must have a knowledge of the regular court trial rules, plus the knowledge of when and to what degree he may take liberties. In other words, he must know the regular rules first, and then acquire a familiarity with the "irregular" rules, so to speak, allowed in administrative hearings, such as those before a commission.

Unless the rate case lawyer is thus doubly equipped, he is under a handicap, not only in exercising the full latitude which the presentation of his own client's case may require, but he may also fail to call a halt when other parties in the case try to take too many liberties." 
together with some adaptations from the inquisitorial system of trial, perhaps, with a view to effecting an acceptable and just result in each particular case.

Most people are familiar, at least in a general way, with the famous Army-McCarthy hearings held about ten years ago in the U.S. This, in part, is what the late Joseph N. Welch, special counsel for the Army, had to say about them:

Once, in what now seems like the long ago, I went to some hearings conducted by the late Senator Tobey on the matter of business firms owned by charitable trusts; I attended on behalf of a pension fund I represented. Once I got a few fleeting glimpses on television of a one-man hearing that Senator McCarthy conducted in Boston. But not until fate rather strangely took me from Boston to Washington as counsel at the Army-McCarthy hearings had I seen a full-dress congressional investigation. If you, the reader, watched the hearings and found them a novel, startling and sometimes bewildering experience, you are pondering the words of a kindred soul.

What chiefly impressed me as a lawyer, I suppose, was what you might call the free-wheeling characteristics of the hearings. The only rule you could really be sure of was that they would start around 10 a.m. and run until 12:30, then resume again from $2 \mathrm{p.m}$. to around 5 . On the way to the hearing room it was impossible to predict what would happen between $10 \mathrm{a.m}$. and 5 p.m.; on the way back it was sometimes hard to believe what had happened.

After the hearings were over a lawyer friend said to me, "There was just no wall against which you could back a witness and make him act like a witness. That was the chief trouble".

What he observed was true, agonizingly so at times. There was no wall standing firm at the back of the room labelled "relevancy", no wall at right angles labelled "competency", no wall parallel to this bearing the sign "materiality". Thus there was no chance of confining a witness or a cross-examiner to the necessary limits within which the blessed logic of courtroom practice dictates that facts in dispute should be presented and weighed.

All in all it was a strange experience for a lawyer unfamiliar with Washington. We seemed to be trying the case before a court, or the parallel of a court, or some kind of approximation of a court, with seven judges. Or were they perhaps jurors? (If they were jurors, it was odd to have them asking questions and even testifying). ${ }^{3}$

Now, although Mr. Welch was speaking about a "full-dress congressional investigation", what he said can be apposite to a quite ordinary administrative proceeding at the local, provincial or federal level in Canada, or to such a proceeding of lesser notoriety in the United States. And counsel engaged in such proceedings should keep $\mathrm{Mr}$. Welch's remarks in mind, particularly those on "relevancy", competency" and "materiality".

One of the most significant problems to be considered by counsel in administrative proceedings is the extent to which the ordinary rules of evidence do or do not apply. If he is counsel to the agency itself, it may be that to a considerable degree the responsibility for attempting to solve this problem will devolve upon him. I do not mean to suggest that the agency should abdicate to its counsel responsibility in matters of evidence and procedure; but, the fact of the matter is, he is the agency's legal assistant, most or perhaps all of its members do not have a legal training, and certainly part of his role is to see to it that a workable plan of fair procedure is arrived at-and the sooner this is done the better for all concerned. On the other hand, if the laywer is counsel for an interested government or an interested party or an intervenant, it is his duty

3 The Lawyer's Afterthoughts, Life Magazine, July 26, 1954, at 97. 
to co-operate in the formulation of a plan of procedure which will ensure that his client's interests are protected, to make sure that his client's witnesses will not be dealt with improperly, and, like counsel to the agency, to see to it that the common good will be served. Accordingly, it is desirable that, to the extent necessary, counsel to the agency and the other counsel involved should take the time and exert the energy necessary to hammer-out together some ground-rules which take account of the exigencies of the particular case. Perhaps the following-prepared by the writer and used in an inquiry which involved a government agency, local governments, a privately-owned utility corporation, and interested citizens-will serve to illustrate:

1. All evidence tendered should be upon oath or affirmation, and all documentary evidence should be so verified. There should be opportunity for examination-in-chief, cross-examination, re-examination, examination by counsel to the administrative agency, and examination by members of the agency itself. The agency should make no findings on evidence which has not been open to questioning.

2. The agency should not treat the findings of (a certain prior royal commission) as final, but should review all relevant evidence and reach its own conclusion: in other words, the agency should not abdicate its function (under the Act) in favour of the report of that commission. The commission's report may be received as an exhibit, as may evidence in support thereof, for identification only.

3. The "best evidence rule" should be followed with reference to documentary evidence, so far as is practicable-i.e., the mere recollections, interpretations or opinions of witnesses should not be received regarding the contents of documents where those documents are available.

4. All witnesses who testify should state in detail their own qualifications to speak on the matter in question, especially where opinion evidence is proposed to be given.

5. The burden or onus of proof should be upon (the corporation) to establish the matters relevant under (the Act). This is in accordance with the nature of the inquiry, and the fact that the information in question is or should be in the possession of (the corporation)."

6. Subject to proof of formal matters by counsel to the agency, e.g., statutory notices, (the corporation) should initiate the introduction of evidence, putting in the whole of its case in continuous and so far as is practicable chronological order, touching upon the various points as they appear in (the Act).

7. The various interested parties and intervenants should, in turn, be entitled to question each witness called by (the corporation), as called, in such order as the agency, in its discretion, may determine. Then counsel to the agency and members of the agency may put questions to each witness.

4 Burden or onus of proof can have a very important practical effect in administrative proceedings. For example, where a public utility operates under the "prudent acquisition" concept, is there a presumption of prudence, or must the corporation demonstrate It? In In the Matter of Greater Winnipeg Gas Company (Determination of Rate Base). Order No. 327 $/ 65$, The Manitoba Public Utilities Board held that the utility corporation must demonstrate prudence. that there is no presumption in favour of the corporation. And see, Welch, ante, n. 2 , at 205, and Jaffe, Judicial Control of Administrative Action 607-609 (1965), as to burden of proof generally in administrative proceedings. 
8. (The corporation) should then close its submission of evidence, subject to the right to tender rebuttal evidence, and subject to a privilege of re-opening to tender further evidence in the discretion of the agency.

9. Each party or intervenant who enters an appearance on the record should, in turn, be entitled to tender evidence as above.

10. (The corporation) and each party or intervenant who enters an appearance on the record should be entitled to address the agency in the order above-mentioned, followed by counsel to the agency.

11. Neither (the corporation) nor any party or intervenant who enters an appearance should be regarded as being "on trial", and counsel to the agency should not be regarded as being counsel for any particular party or intervenant in the proceedings. The function of counsel to the agency is to assist the agency in its endeavour to determine the matters in issue under (the Act). ${ }^{5}$

12. The foregoing is neither exhaustive nor final. It is realized that the procedure finally laid down may have to be departed from according to circumstances as they arise ... this in the discretion of the agency.

In those cases in which the agency has advisers or consultants appointed to assist it, the question arises as to whether they and the agency's own staff should testify and be subject to cross-examination. In the proceedings where the foregoing plan of procedure was used, they did not testify. ${ }^{\circ}$

Having worked out a set of ground-rules which appear suited to the particular case, perhaps the next logical step is to give consideration to the following problem areas: (1) hearsay, (2) opinion, (3) similar facts, (4) official or judicial notice and knowledge, and (5) examination of witnesses and privilege. Of course, there are many other problem areas, but these are the main evidentiary ones, and the ones which will be discussed here.

Counsel, while considering these problem areas, would be well advised to ponder the extent to which an administrative proceeding that ignores or strays very far from Mr. Welch's "blessed logic of courtroom practice" will be likely to be "acceptable as having been properly made" and be likely to meet the characteristics "openness, fairness and impartiality".?

6 Perhaps he should proceed in a manner analagous to Crown counsel in a criminal matter. See, Turner, The Role of Crown Counsel in Canadian Prosecutions (1962), 40 Can. Bar Rev. 439.

o Welch, ante, n. 2, at 215-216: "Where the commission has suspended a proposed rate change, or entered into investigation of an existing rate or issued to a "show cause" order, the staff may and generally does assume the practical position of a party to the case. It may call its own witnesses, including "outside witnesses", not regularly employed as staff members. It may, in other ways, offer affirmative or negative evidence in the form of exhibits. Commission counsel may (and often does, under such circumstances) cross-examine witnesses for other parties and call witnesses in rebuttal.

About the only restriction imposed on the commission's use of its own witnesses is that they must be avallable for cross-examination. Commission engineering reports submitted after hearings, without opportunity on the part of a utility party to inspect or examine, have been ruled inadmissible.

The United States circuit court of appeals for the District of Columbia has ruled that the Federal Power Commission may proceed on the basis of an expert accountant's testimony, regardless of whether he is a member of the staff, retained by the staff, or a regulated utility, as long as the commission is satisfied as to the integrity of the witness."

7 See, Report of the Committee on Administrative Tribunals and Enquiries (England, Her Majesty's Stationery Office, 1957, reprinted 1962). 


\section{HEARSAY}

"By the law of England evidence is not admissible through the mouth of one witness to show what a third person said for the purpose of proving the truth of what that third person said because (1) to admit such evidence would be to accept the statement of a person not on oath, and (2) because that person cannot be cross-examined on his statement. But the evidence may be admitted on some other principle. The maxim 'hearsay is no evidence' should be 'hearsay is no evidence of the truth of the thing heard" "- that is the rule as it was expressed by Sir John Simon in Rex. v. Christie. ${ }^{8}$ However, the rule against admission of hearsay is subject to many qualifications and exceptions, with the result that in many cases hearsay is admitted and weighed by the court, either alone or along with the other evidence in the case. And this is done in the most serious and important criminal cases, as well as in lesser criminal and civil cases. Accordingly, it is not correct to say that courts never act upon hearsay.

Disagreement is to be found among the leading authorities on the law of evidence as to just what are the exceptions. This is not the place to discourse on this disagreement, or to run the risk of muddying the waters any more than they are at present by attempting to spell them all out. Among the exceptions which the common law has recognized are: Declarations by deceased persons which satisfy the conditions allowing for admission of dying declarations (but, seemingly, only in criminal cases); declarations by deceased persons against pecuniary or proprietory interest; declarations by deceased persons in the course of duty; declarations by deceased persons as to public matters; and declarations by deceased persons as to contents of their wills. Also, perhaps, declarations as to bodily or mental feelings and spontaneous exclamations may be admitted. In addition, confessions by an accused person, and admissions by a party or his representative in civil actions, may be admitted, as may testimony in former proceedings and official statements in public documents. Some jurisdictions have a special legislative exception which is sometimes overlooked. ${ }^{9}$

There has been a good deal of criticism directed against the rule excluding hearsay. ${ }^{10}$ Of course, quite apart from the absence of an oath, the real objection to the admissibility of hearsay is that there is no opportunity for cross-examination of the original declarant. But that is so even in those cases where hearsay is admitted under the exceptions. Whatever may be the case where jury trials are concerned, the better view would seem to be, to allow admission of hearsay in non-jury type proceedings so that the tribunal can weigh it, for whatever it may be worth. If it is found to have little or no weight, then it should be disregarded or regarded only slightly. A failure to follow this course in administrative proceedings may well result only in the agency becoming hopelessly involved in a mass of technicalities as to admission or rejection of the questioned evidence-one of the very things which the setting up of the agency was intended to avoid in the first place.

8 [1914] A.C. 545.

9 See, e.g.o s. 54 of The Manitoba Evidence Act, R.S.M. 1954, c. 75. This relates to outof-court statements which have been reduced to writing.

10 See, e.g., Frank, Courts on Trial 123 (1950). 
In United States v. United Shoe Machinery Corp.,11 Judge Charles E. Wyzanski, Jr., made the following observation:

So far as this Court is aware, the Supreme Court has never either reversed or criticized a trial court for admitting hearsay evidence in a civil anti-trust case tried without a jury. And all federal courts in anti-trust cases do receive, though perhaps on grounds which would be indefensible in a simple tort or contract case, the intramural communications passing between agents of the same corporation. (Citations omitted.) That tolerance is not properly attributable to a crusading spirit of an attitude of hostility toward business. It developed in the light of the rule that, even without explicit statutory permission, the Federal Trade Commission may utilize hearsay evidence in making findings: Phelps Dodge Refining Corp. v. Federal Trade Commission12. " . . Rules which bar certain types of evidence in criminal or quasi-criminal cases are not controlling in proceedings ... . where the effect of the Commission's order is not to punish or to fasten liability on respondents for past conduct but to ban specific practices for the future in accordance with the general mandate of Congress": Federal Trade Commission v. Cement Institute. ${ }^{18}$

It is difficult to imagine any satisfactory ground for deciding that evidence which is admissible before the Federal Trade Commission is inadmissible before a judge sitting without a jury in a civil anti-trust case brought by the Government. There is no difference between the substantive anti-trust law applied by the Commission and that applied by the Court. In a civil anti-trust case the Government has the unfettered choice of going before a Commission or before a court without a jury. The Commission's cease and desist order may in many cases be as drastic as the decree of a District Court, except for the one point that the District Court's decree unlike the Commission's order can be used as prima facie evidence in a private treble damage suit.14 The Commission's hearing officer may be no more experienced or skillful than a District Judge in sifting the reliable hearsay from the untrustworthy hearsay. And the admission of hearsay evidence by a Commission undercuts just as effectively as the admission of hearsay evidence by a Court the fundamental objective of the hearsay rule-the opportunity to hear the witness under oath and to subject him to cross-examination.

One other consideration deserves mention. Recent years have seen a marked increase in the number of social and economic controversies which have been removed from the courts to administrative agencies for adjudication. Since there is a widespread belief that administrative adjudication gives less security to private interests than does judicial process: $\mathrm{Ng}$ Fung $\mathrm{Ho} \mathrm{v}$. White, ${ }^{15}$ many persons regret this trend. Yet the original demand for administrative adjudication was traceable, in part at least, to the unwillingness of courts to admit evidence which they allowed administrative agencies to receive and act upon. And that demand would be reinforced if the courts were to continue to say that in social and economic controversies where the remedy is not imprisonment, or fine, or damages but an order prescribing future conduct, a court sitting without a jury cannot receive hearsay evidence even though without statutory authority an administrative agency could do so. To preserve their own jurisdiction the courts must in this type of controversy relax the rigidity of the hearsay rule.16

The unfortunate "residuum rule" (so-called) was dealt with in the case of Carroll v. Knickerbocker Ice Co., ${ }^{17}$ where an award was made by workmen's compensation agency solely upon statements made by the deceased workman that a block of ice had fallen upon him. Three witnesses testified that they were present and saw no accident, and three physicians testified that they found no marks on the body. The governing statute provided that "common law or statutory rules of evidence" were not binding on the agency. It was held that while the Commission's inquiry was not limited by common law or statutory rules of evidence

\footnotetext{
11 (1950), 89 F. Supp. 349.

12 (1943), 139 F.(2d) 393, 397 (Second Cir.).

18 (1948) 333 U.S. 683, 706; 68 S. Ct. 793, 806; 92 L. Ed. 1009.

1415 U.S.C.A. S. 16.

15 (1921), 259 U.S. 276, 285; 42 S. Ct. 492; 66 L. Fd. 938.

16 (1950), 89 F. Supp. 349, 355, 356.

17 (1916), 113 N.E. 507. Compare, Youlden v. London Guarantee and Accident Co. (1913), 12 D.L.R. 433 (Ont. C.A.), and Davis v. Fortior, Ltd., [1952] 1 AII F.R. 1359, as to admissibility of statements made by an accident victim at or about the time of the accident.
} 
or by technical or formal rules of evidence or by technical or formal rules of procedure, and that it might, in its discretion, accept any evidence offered, still in the end there had to be a residuum of legal evidence to support the claim before an award could be made. The Commission's award was not upheld. In United States ex rel. Dong Wing Ott v. Shaughessy ${ }^{18}$ it was said that, "The status of the residuum rule is by no means crystal clear in the federal courts (even though) Congress has explicitly avoided the requirement of competent evidence to support findings in the Administrative Procedure Act."18 According to Professor Davis, "The residuum rule is probably not the law of the federal courts. Yet the federal case law does not support an unqualified statement that the residuum rule is uniformly rejected ... the rejection of the rule is incomplete."20 Dean Wigmore, referring to Carroll v. Knickerbocker, ${ }^{21}$ says, "Plausible as this rule seems, from the liberal point of view, yet it is not acceptable." He contends that it holds out to practitioners the temptation "to employ the whole arsenal of technical weapons and secure a record full of 'error' "22 Of course, he is right. It is submitted that the residuum rule should not be used in Canada, and that the matters of admission and rejection, and weighing of evidence should be left to the discretion of the agency-the body which has the responsibility placed upon it by the legislature-unfettered by the confines of the chamber of horrors in which resides the hearsay rule with its exceptions, qualifications and absurdities.

English support for this view can be found in the case of $R$. v. Deputy Industrial Injuries Commissioner, Ex parte Moore, ${ }^{23}$ where medical witnesses testifying, not under oath, before a claims commissioner referred to medical opinions expressed by two unnamed doctors in a previous case. The commissioner regarded those opinions as part of the evidence in the case at hand. This was approved by the English Court of Appeal, even though neither of the other doctors was made available for cross-examination before the commissioner. The obligation of the commissioner to proceed in accordance with natural justice, ordinary rules of evidence apart, was held to have been met. ${ }^{24}$

This case exemplifies the proposition that the rules of evidence applicable in proceedings in a court of law form no essential part of the principles of natural justice; and, by the same token, it has been held in the United States that they form no essential part of the constitutional requirement of "due process of law". The same view may well be taken so far as "due process" under the Canadian Bill of Rights is concerned.25

18 (1952), 116 F. Supp. 745.

19 Id. at 750 .

20 Davis, Administrative Law (Cases, Text, Problems) 262 (1965).

21 Ante, n. 17.

22 Wigmore on Evidence, Vol 1, p. 40 (3d. ed.).

23 [1965] 1 All E.R. 81.

24 The Court relied upon the leading case of Board of Education v. Rice, [1911-13] All E.R. 36; [1911] A.C. 179, which, in the absence of specific legal requirements to the contrary, permits administrative agencies "to obtain information in any way they think best, always giving a fair opportunity to those who are parties to the controversy of correcting or contradicting any relevant statement prejudicial to their vlew."

25 See, generally, Guay v. Lafleur, [1965] S.C.R. 12. It was held that an inquiry under s. 126 of the Income Tax Act was a purely administrative matter, and that Lafleur was not entitled to counsel. If that is so, then there could be no obligation to follow the ordinary rules of evidence. [The court held however that s. $2(e)$ of the Canadian Bill of Rights was not applicable since no rights and obligations were determined by the investigator.-Ed.] 


\section{OPINION}

Administrative agencies, by reason of the very nature of their work, frequently have to depend to a large extent upon opinion testimony. It is to be expected, therefore, that no undue technicalities should be laid in the way of their doing so.

In the ordinary courts of law, the general rule is that opinion evidence should not be admitted. Rather, the witnesses should be required to state matters of fact within their own knowledge, and not merely their opinions. However, necessarily, there are exceptions: (1) opinions of skilled witnesses, e.g., medical doctors, are admissible whenever the subject is one upon which competency to form an opinion can only be acquired by a course of special study or experience, and, (2) opinions of non-experts are admitted to establish identity, handwriting, age, speed, and such matters, where more direct and postive evidence is often unobtainable. ${ }^{28}$

The case of Reilly v. Pinkus ${ }^{27}$ dealt with a federal statute authorizing the Postmaster General to forbid delivery of mail and payment of money orders to "any person or company" found "upon evidence satisfactory" to him to be "conducting any ... scheme or device for obtaining money ... through the mails by reason of false or fraudulent pretenses, representations, or promises . . ." The Postmaster General, following a hearing, issued such an order restricting the respondent's use of the mails.

The representations in question related to an anti-fat treatment. It was represented that one could eat plenty, and yet reduce. The fat reducing power of the respondent's product was chiefly attributed to iodine. There was, of course, conflicting medical testimony for both sides of the case. The District Court granted a decree against enforcement of the order on the ground that the order was unsupported by factual evidence. It was asserted that there was "no exact standard of absolute truth" against which the respondent's advertisements could be measured, and the Court held that the testimony of the two doctors on which the government's case rested was reduced by the conflicting testimony of the respondent's medical witness to the status of mere opinions. The Court of Appeals affirmed, and the Supreme Court granted certiorari.

Speaking for the Supreme Court, Mr. Justice Black held that the decision of the Court of Appeals should be affirmed, and had this to say of signifigance to the subject of administrative evidence:

... [W] are constrained to hold that the present fraud order should not be enforced. It has been pointed out that the doctors' expert evidence rested on their general professional knowledge. To some extent this knowledge was acquired from medical books and publications, on which these experts placed reliance. In cross-examination respondent sought to question these witnesses concerning statements in other medical books, some of which at least were shown to be respectable authorities. The questions were not permitted. We thing this was an undue restriction on the right to cross-examine. It certainly is illogical, if not actually unfair, to permit witnesses to give expert opinions based on book knowledge, and then deprive the party challenging such evidence of all opportunity to interrogate them about divergent opinions expressed in other reputable books.

20 Phipson, Evidence 1280, 1314 (10th ed. 1963).

27 (1949), 338 U.S. 269. 
Petitioner seeks to justify exclusion of cross-examination based on some of these books by pointing out that they were merely medical dictionaries. Government experts testified they would not consult the dictionaries to ascertain the efficacy of a remedy, although they kept and used them for other purposes. But the books did assert the use of kelp as a fat reducer, and to some extent this tended to refute testimony by government experts that no reputable physicians would accept kelp or iodine as a weight reducer.

It is also contended that the error in restricting cross-examination was harmless here because the memorandum of the fact-finding official indicated that he had read the excluded materials and would have made the same adverse findings had the materials been held admissible. But the object of using the books on cross-examination was to test the expert's testimony by having him refer to and comment upon their contents. Respondent was deprived of this opportunity. The error of this deprivation could not be cured by having the fact-finder subsequently examine the material.

Moreover, the issues in post office fraud cases make such cross-examination peculiarly appropriate. Proof of fraudulent purposes is essential-an "actual intent to deceive." See Seven Cases v. United States. ${ }^{28}$ Consequently fraud under the mail statutes is not established merely by proving that an incorrect statement was made. An intent to deceive might be inferred from the universality of scientific belief that advertising representations are wholly unsupportable; conversely, the likelihood of such an inference might be lessened should crossexamination cause a witness to admit that the scientific belief was less universal than he had first testified.

The power to refuse enforcement of orders for error in regard to evidence should be sparingly exercised. A large amount of discretion in the conduct of a hearing is necessarily reposed in an administrative agency. And what we have said is not to be taken as removing this discretion or as a compulsory opening of the gates for floods of medical volumes, even where shown to be authoritative. But in this kind of case as in others, one against whom serious charges of fraud are made must be given a reasonable opportunity to cross-examine witnesses on the vital issue of his purpose to deceive. And in this case any holding of harmless error is precluded by the fact that the assistant solicitor presiding at the hearings adopted the prosecutor's view that respondent was to be barred from using the mails "regardless of the question of good faith, even if the respondent believed in all of his representations ... . if they were false as a matter of fact."29

In administrative cases involving such matters as determining the basis for rates and determining rates themselves, it is not unexpected that an agency should have the benefit of expert opinions as to "reasonableness". And in cases requiring a determination as to whether an application for a securities broker's license should be granted, opinions as to character may play a substantial part in the decision. It is sometimes said that asking a witness the very question which a tribunal has to decide, should not be permitted. There may be justification for such a limitation where a matter is being tried before a jury, but it does not exist in administrative proceedings. In such proceedings the tendency should be to admit everything which may be helpful. The opinion evidence should be heard, and the matter of what weight it should be accorded should be left to the agency.

\section{SIMILAR FACTS}

At common law, "Facts which are relevant merely from their general similarity to the main fact or transaction, and not from some specific connection therewith ... are not admissible to show its existence or occurrence." ${ }^{30}$ But there are many and various qualifications to this proposition, in both civil and criminal cases. What is the situation in administrative proceedings?

28 (1915), 239 U.S. 510, 517.

29 Ante, n. 27, at 275-276.

30 Phipson, ante, n. 19, at 451. 
In WBNX Broadcasting Co. ${ }^{31}$ the Commisison had before it a motion to strike from the record all evidence relating to the content and policies of the applicant's newspapers adduced by the American Jewish Congress. The congress sought to show that the papers had evidenced bias against minority groups, particularly Jews and Negroes, and that the applicant had published irresponsible and defamatory news items and editorials concerning such minorities.

The Commission allowed the evidence, reserved decision on question of what weight should be given to it, and said:

The fairness with which a licensee deals with particular racial or religious groups in the community, in the exercise of his power to determine who can broadcast what over his facilities, is clearly a substantial aspect of his operation in the public interest. Counsel for the News Syndicate, on oral argument, agreed that the Commission could examine the "acts" of an applicant, but not his "language" to determine whether he would be likely to exercise his authority as a licensee with fairness ... Whether or not the applicant is a Democrat or Republican, is Protestant or Catholic or Jewish, is a conservative or radical, or has a personal preference or antipathy for any particular religious or racial group, is not at all the issue. The Commission has not in the past sought to inquire into these matters, and does not propose to do so. The issue, is, rather, whether the applicant, whatever his own views, is likely to give a "fair break" to others who do not share them. To that inquiry, evidence of past conduct which is reasonably indicative of the manner in which the applicant is likely to act in the future, is certainly relevant. But, clearly, that past conduct cannot be the mere expression if views, whether oral or in the pages of a newspaper or periodical, but must plainly constitute acts of unfaimess as, for instance, denial of any opportunity to reply to attacks under circumstances where fair play requires the granting of such an opportunity, or the repeated making of irresponsible charges against any group or viewpoint without regard for the truth of such charges and without bothering to determine in advance of their publication whether they can be corroborated or proven ... 82

One Commissioner dissented on the ground that the evidence was without probative value, and that he knew of no court decision which would support the Commission in examining the news and editorial policies of an applicant's newspaper for the purpose of determining what the policies of the applicant might or might not be in the future operation of a proposed broadcast station.

It would seem that the Commission's approach was the correct one. The information should be weighed by it, having regard to the problem of "the public interest" involved. On the other hand, a criminal proceeding or a civil issue between two parties submitted for decision to a regular court of law might more properly be handled in the traditional manner which, as a general rule, rejects evidence of prior and subsequent conduct.

In arbitration proceedings in connection with an expropriation, evidence of a sale after expropriation has, in the absence of special circumstances, been held to be relevant evidence of value, provided the sale is free from extraneous factors and made before prices changed materially as a result of the expropriation. ${ }^{38}$

31 (1948), 12 F.C.C. 837, quoted from Davis, Cases on Administrative Law 532 (1951).

82 Id. at $532-533$.

s3 Re MeCain and City of Saint John (1965), 47 D.L.R. (2d) 164 (N.B.C.A.). 


\section{OFFICIAL (JUDICIAL) NOTICE AND KNOWLEDGE"}

In the ordinary courts judicial notice will be taken of law, procedure, custom, public matters, official gazettes, official seals, signatures, and the like. Also, they will take judicial notice, without further proof, of "notorious facts". When in doubt, the judge may look at the appropriate authorities to refresh his memory..$^{35}$ Of this doctrine Professor Thayer long ago observed:

The subject of judicial notice . . . belongs to the general topic of legal or judicial reasoning. It is, indeed, woven into the very text of the judicial function. In conducting a process of judicial reasoning, as of other reasoning, not a step can be taken without assuming something which has not been proved (footnote omitted) and the capacity to do this, with competent judgment and efficiency, is imputed to judges and juries as part of their necessary mental outfit.86

So far as administrative agencies are concerned, it should be kept in mind that the matters referred to them have been referred to them because it is thought that those matters are not, for one reason or another, appropriate to be dealt with in the ordinary courts of law. One might expect, therefore, that the persons who staff these agencies will have or will acquire a special familiarity with or expertise in the subject matters falling within the agencies' jurisdictions. ${ }^{37}$. Accordingly, one might further expect that there will exist an area for the exercise of judicial or official notice somewhat broader than that which would ordinarily exist. There are, however, limits to the extent to which agencies may rely on their own knowledge.

This is illustrated in the case of ICC v. Louisville \& Nashville R. $R .^{38}$ where the government insisted that an agency's order, based upon its own opinion as to proper rates, could not be set aside even if the finding was wholly without substantial evidence to support it. The Supreme Court disposed of that contention in the following terms:

$\ldots$ [T] of introducing testimony, and at the same time imposed the duty of deciding in accordance with the facts proved. A finding without evidence is arbitrary and baseless. And if the Government's contention is correct, it would mean that the Commission had a power possessed by no other officer, administrative body, or tribunal under our Government. It would mean that where rights depended upon facts, the Commission could disregard all rules of evidence, and capriciously make findings by administrative fiat. Such authority, however beneficiently exercised in one case, could be injuriously exerted in another, is inconsistent with rational justice, and comes under the Constitution's condemnation of all arbitrary exercise of power...

The Government further insists that the Commerce Act ... requires the Commission to obtain information necessary to enable it to perform the duties and carry out the objects for which it was created, and having been given legislative power to make rates it can act, as could Congress, on such information, and therefore its findings must be presumed to have been supported by such information, even though not formally proved at the hearing. But such a construction would nullify the right to a hearing,-for manifestly there is no hearing when the party does not know what evidence is offered or considered and is not given an

34 On this subject generally, see: Schiff. The Use of Out-of-Court Information in Fact

Determination at Trial (1963), 41 Can. Bar Rev. 335; Davls, Judicial Notice (1955), 55

Col. L. R. 945; Davis, Official Notice (1949), 62 Harv. L. R. 537.

ss Phipson, ante, n. 19, at 46.

36 Thayer, Evidence, 279-280 (1898).

37 But, see, Jaffe, ante, n. 4 at 25: "But, it will be asked, are these agencies as we know them, "expert"'? Is their expertness significant? It can be instanced, for example, that the Civil Aeronautics Board for a time encourages competition (perhaps by a vote of 3-2) and then-perhaps there is a shift in Board membership-reverses its stand by the same vote (footnote omitted). The picture can be helghtened by adding that the Board appointments are political, and that those with the longest tenure are "Iame ducks" who cannot get a job elsewhere. Is this your much vaunted "expertise"? Let us start then by confessing that the plcture does have disturbing aspects."

38 (1913), 227 U.S. 88, quoted from Davis, ante, n. 31, at 537. 
opportunity to test, explain, or refute. The information gathered under the provisions of $\mathrm{s}$. 12 may be used as basis for instituting prosecutions for violations of the law, and for many other purposes, but is not available, as such, in cases where the party is entitled to a hearing. The Commission is an administrative body and, even where it acts in a quasi-judicial capacity, is not limited by the strict rules, as to the admissibility of evidence, which prevail in suits between private parties: Interstate Commerce Commission v. Baird. ${ }^{30}$ But the more liberal the practice in admitting testimony, the more imperative the obligation to preserve the essential rules of evidence by which rights are asserted or defended. In such cases the Commissioners cannot act upon their own information as could jurors in primitive days. All parties must be fully apprised of the evidence submitted or to be considered, and must be given opportunity to cross-examine witnesses, to inspect documents and to offer evidence in explanation or rebuttal. In no other way can a party maintain its rights or make its defense. In no other way can it test the sufficiency of the facts to support the findings; for otherwise, even though it appeared that the order was without evidence, the manifest deficiency could always be explained on the theory that the Commission had before it extraneous, unknown but presumtively sufficient information to support the finding. 10

And in United States \& ICC v. Abilene \& Southern Ry Co., ${ }^{41} \mathrm{Mr}$. Justice Brandeis, speaking for the Court, observed:

The plaintiffs contend that the order is void because it rests upon evidence not legally before the Commission. It is conceded that the finding rests, in part, upon data taken from the annual reports filed with the Commission by the plaintiff carriers pursuant to law; that these reports were not formally put in evidence; that the parts containing the data relied upon were not put in evidence through experts; that attention was not otherwise specifically called to them; and that objection to the use of the reports, under these circumstances, was seasonably made by the carriers and was insisted upon. The parts of the annual reports in question were used as evidence of facts which it was deemed necessary to prove, not as a means of verifying facts of which the Commission, like a court, takes judicial notice. The contention of the Commission is that, because its able examiner gave notice that "no doubt it will be necessary to refer to the annual reports of all these carriers," its Rules of Practice permitted matter in the reports to be used as freely as if the data had been formally introduced in evidence.

The mere admission by an administrative tribunal of matter which under the rules of evidence applicable to judicial proceedings would be deemed incompetent does not invalidate its order: Interstate Commerce Commission v. Baird;42 Spiller v. Atchison, Topeka \& Santa Fe Ry. Co.43 Compare Bilokumsky v. Tod. ${ }^{44}$ But a finding without evidence is beyond the power of the Commission. Papers in the Commission's files are not always evidence in a case: New England Divisions Case.15 Nothing can be treated as evidence which is not introduced as such: Interstate Commerce Commission v. Louisville \& Nashville R.R. Co.;40 Chicago Junction Case. 47 If the proceeding had been, in form, an adversary one commenced by the Orient system, that carrier could not, under Rule XIII, have introduced the annual reports as a whole. For they contain much that is not relevant to the matter in issue. By the terms of the rule, it would have been obliged to submit copies of such portions as it deemed material; or to make specific reference to the exact portion to be used. The fact that the proceeding was technically an investigation instituted by the Commission would not relieve the Orient, if a party to it, from this requirement. Every proceeding is adversary, in substance, if it may result in an order in favour of one carrier against another. Nor was the proceeding under review any the less an adversary one, because the primary purpose of the Commission was to protect the public interest through making possible the continued operation of the Orient system. The fact that it was on the Commission's own motion that use was made of the data in the annual reports is not of legal significance. ${ }^{8} 8$

The authorities dealing with the extent to which agencies may take official notice of facts not on the record are not easily reconcilable, and

30 (1903), 195 U.S. 25.

40 Ante, n. 38, at 537-538.

41 (1924), 265 U.S. 274, quoted from Davis, ante, n. 31, at 539

42 (1904); 194 U.S. 25, 44.

43 (1919), 253 U.S. 117, 131.

44 (1923), 263 U.S. 149, 157.

45 (1922); 261 Ư.S. 184, 198 n. 19.

46 (1912); 227 U.S. 88, 91,98 .

17 (1924); 264 U.S. 258.

18 Ante, n. 41, at 539-541. 
in some cases seem not to be reconcilable at all. As a matter of practice, it is suggested that a proper approach to the problem would be one along the following lines: Where an agency proposes that it should, without any formal proof, take notice of certain matters, whether they be in its own files or otherwise, it should in fairness draw this to the attention of all parties or intervenants in order to enable them to deal with it or adduce contrary or qualifying information. If, for example, the agency intends to use a certain formula in connection with a rate case, perhaps being one which it thought it had used satisfactorily in another such case, the agency should bring this fact to the attention of all those concerned and afford them an opportunity to contest it. The problem is well illustrated in the case of Ohio Bell Tel. Co. v. Public Utilities Commission $^{\star 0}$ where Mr. Justice Cardozo, delivering the opinion of the Supreme Court, stated:

The Commission did not confine itself . . . to a valuation of the property as of the date certain. It undertook also to fix a valuation for each of the years 1926 to 1933 inclusive. For this purpose it took judicial notice of price trends during those years, modifying the value which it had found as of the date certain by the percentage of decline or rise applicable to the years thereafter. The first warning that it would do this came in 1934 with the filing of its report [accompanying the order] ... The company protested and moved for a rehearing. In its protest it stated that the trend percentages accepted in the findings as marking a decline in values did not come from any official sources which the Commission had the right to notice judicially; that they had not been introduced in evidence; that the company had not been given an opportunity to explain or rebut them; and that by their use of the Commission had denied a fair hearing in contravention of the requirements of the Fourteenth Amendment. Demand was made that an opportunity be conceded for explanation and rebuttal ... By order dated March 1, 1934, the protests were overruled, and the demands rejected ...

The fundamentals of a trial were denied to the appelant when rates previously collected were ordered to be refunded upon the strength of evidential facts not spread upon the record ....

Courts take judical notice of matters of common knowledge ... They take judicial notice that there has been a depression, and that a decline of market values is one of its concomitants. .. How great the decline has been for this industry or that, for one material or another, in this year or the next, can be known only to the experts, who may even differ among themselves ...

From the standpoint of due process-the protection of the individual against arbitrary action-a deeper vice is this, that even now we do not know the on which it rested its conclusion. Not only are the facts unknown; there is no way to find them out. When price lists or trade journals or even government reports are put in evidence upon a trial, the party against whom they are offered may see the evidence or hear it and parry its effect. Even if they are copied in the findings without preliminary proof, there is at least an opportunity in connection with a judicial review of the decision to challenge the deductions made from them. The opportunity is excluded here. The Commission, withholding from the record the evidential facts that it has gathered here and there, contents itself with saying that in gathering them it went to journals and tax lists, as if a judge were to tell us, I looked at the statistics in the Library of Congress, and they teach me thus and so. This will never do if hearings and appeals are to be more than empty forms ... .

\section{EXAMINATION OF WITNESSES AND PRIVILEGE}

Where a tribunal is so constituted that it has the powers and privileges of a court of record but is not bound by the rules of evidence, it may be a nice question as to just how it should proceed so far as examination of witnesses and privilege are concerned.

As to the first point, it is submitted that Wrottesley's observation is pertinent-"No better mode of ascertaining the truth of a past transaction

49 (1937), 301 U.S. 292

so Id. at $296-303$. 
will probably ever be devised by human ingenuity than the present method of viva voce examination of witnesses, conducted as it is in open court, in the sight of the public and in the presence of the parties, their counsel, and of the Judge and Jury, who all have an opportunity of observing the intelligence, demeanour, inclination, bias or prejudice of the witnesses." ${ }^{51}$

This, it is suggested, is just as applicable to administrative proceedings as it is to judicial, and the usual course of examination-in-chief, cross-examination, and re-examination followed by questions, if any, from the agency, should be adopted so far as is practicable. Counsel, if he wishes his witnesses to leave a weighty impression with the agency, should refrain from "leading" on material matters, lest the process of questionand-answer be reduced to a situation where counsel is giving the testimony while the witnesses, puppet-like, merely affirm, disaffirm or qualify it. Similarily, in cross-examination, the usual procedures regarding contradiction, and the like, should be followed; but, as is the case in some jurisdictions, the rule limiting cross-examination to matters dealt with on examination-in-chief should not be followed in the absence of some compelling reason to the contrary. ${ }^{52}$

With reference to privilege and public policy, it is submitted that a legislative provision which in general terms provides that an agency is not bound by the rules of evidence, or the like, should not automatically be taken as relieving the agency of an obligation to respect matters of public policy and privilege-i.e., state communications (or government secrets), judicial disclosures, disclosures for detection of crime, offers without prejudice, illegally obtained evidence, recognized confidential communications, husband-and- wife communications and immunities, selfincrimination, and the like. ${ }^{53}$ These, it is submitted, are something more than mere rules of evidence, and before ignoring them an agency should have a special, not merely a general, legislative fiat. Where, as may be the case, a court would have a discretion under one of these headings, an administrative agency should, in exercising its discretion, act just as cautiously and fairly as a court.

Perhaps a few words are in order so far as self-incrimination is concerned. In Canada the common law privilege against self-incrimination has been been virtually done away with. Section 5 of the Canada Evidence $A c t,{ }^{54}$ for example, provides as follows:

(1) No witness shall be excused from answering any question upon the ground that the answer to such question may tend to criminate him, or may tend to establish his liability to a civil proceeding at the instance of the Crown or of any person.

(2) Where with respect to any question a witness objects to answer upon the grounds that his answer may tend to criminate him, or may tend to establish his liability to a civil proceeding at the instance of the Crown or of any person,

51 Wrottesley, Examination of Witnesses 16 (2d. ed.).

62 See, Jones v. Burgess (1914), 43 N.B.R. 126, and Editor's Note, 18 Can. Ab. 1198 . See, also, Morgan, Maguire and Weinstein, Evidence Cases and Materials 256-259 (4th ed. 1957), where the English and American rules are discussed.

58 Welch, ante, $n$. 2, at 217: "Income tax returns, sought to be subpoenaed for use as an admission of earnings, were held not subject to subpoena upon objection as to their admission of earnings, were held not subject to subpoena upon objection as to their privileged character. Public utility companies, in view of the necessary publicity given their taxes during routine presentation of rate case evidence as to operating expenses, may decide for policy reasons to waive any objection to the production of such evi-
dence on grounds of privlege. But there can be little question that utilty tax returns are privileged and confidential just as much as the income tax returns of other persons or corporations."

o4 R.s.C. 1952 , c. 307 . 
and if but for this Act, or the Act of any provincial legislature, the witness would therefore have been excused from answering such question, then although the witness is by reason of this Act, or by reason of such provincial Act, compelled to answer, the answer so given shall not be used or receivable in evidence against him in any criminal trial, or other criminal proceeding against him thereafter taking place, other than a prosecution for perjury in the giving of such evidence.

Similar provincial legislation exists. However, before some administrative agencies, the privilege is as follows:

(1) No person shall be excused from testifying or from producing any book, document, or paper in any investigation or inquiry by, or upon a hearing before the board when ordered so to do by the board, upon the ground that the testimony or evidence, book, document or paper required of him may tend to incriminate him or subject him to penalty or forfeiture; but except for prosecution or punishment for perjury committed by him in his testimony before the board, no person shall be prosecuted, punished or subjected to any penalty or forfeiture for or on account of any act, transaction, matter or thing concerning which he has, under oath, testified or produced documentary evidence.

(2) No member or employee of the board shall be required to give testimony in any civil suit to which the board is not a party, with regard to information obtained by him in the discharge of his official duties in connection with the board.

(3) Nothing in this section is intended to give, or gives to any corporation immunity of any kind.55

Counsel should, therefore, be on the look-out for departures from the usual law on these subjects.

The agency and counsel should keep in mind that any attempt to run rough-shod over the usual rights and privileges of a witness, that is, those enjoyed in a court of law, will most certainly not be calculated to meet the characteristics "openness, fairness and impartiality" referred to earlier in this article. ${ }^{56}$ And in an age of creeping (or galloping) socialism, so-called, where administrative agencies play such a signifigant role in social order and reorganization, great care should be exercised to preserve the usual processes so happily associated with civil liberties and rights of the individual. The ordinary intelligent man does not want pie-in-the-sky at the expense of his own rights and personal dignity, if he wants it at all.

\section{CONCLUSION}

... [T] he subject of "administrative law" exists only in the minds of academicians, while practitioners, administrators and judges are experienced enough not to fall into such a trap. ${ }^{5}$

In enacting legislation providing that administrative agencies should not be bound by the ordinary rules of evidence the legislatures sought to avoid two extremes. On the one hand, they could not have intended that the agency should proceed as would a criminal court, or even a civil court. On the other hand, they could not have intended that the agency should proceed without any regard whatever to some evidentiary groundrules, or in a manner reminiscent of Star Chamber. As has been seen, even a midway approach, such as the residuum rule was no doubt thought to be, does not provide the final answer because it, too, may defeat the purpose which the legislature had in mind.

Of course, distinction must be noted between administrative action in the following forms: (1) authoritative exhortation; (2) informative

55 The Public Utilities Board Act, (Man.) 1959, c. 51, s. 25.

5 see ante, n. 7 .

oi See, Shapiro, The Choice of Rulemaking or Adjudication in the Development of Administrative Policy (1965), 78 Harv. L. R. 921, 923, referring to Westwood, The Davis Treatise: Meaning to the Practitioner (1959), 43 Minn. L. Rev. 607, 610-11. 
investigation (inquiry); (3) adjudication (decision-making), and (4) straight-line delegated legislation (rule or regulation-making). Rulemaking allows more scope for disregard of evidentiary principles and concepts than does decision-making.

In his article, referred to at the beginning of this article, Mr. Joseph $\mathrm{N}$. Welch remarked upon a strange experience he had had in Washington -free-wheeling hearings where about the only rule one could be sure of was the times of the sittings. Also, the impossibility of predicting what would happen during those hours and the difficulty in believing what did happen, the difficulties concerning "relevancy", "competency" and "materiality", and not really knowing whether one was trying a case before a court, or the parallel of a court, or some kind of approximation of a court. In a day when public image seems so very important, procedures such as that will have not merely a tarnishing effect, but rather, a very dangerous result. It is no less important that an administrative agency should have an impeccable public image and the confidence of the public, than that a court of law should have them. Indeed, some agencies deal with matters much more important, socially and financially speaking, than do many ordinary courts. They should not be hampered in their work by archaic rules of evidence whereby the game is apparently played for the game's sake. But, at the same time, there should be a rational basis for predicting what may or may not be regarded as relevant, admissible and cogent in any particular proceeding.

It has been said that "administrative law" does not really exist. That kind of talk reminds one of those who would have us believe that international law and international legal procedure do not really exist. However, fortunately, "saying so does not make it so" and we can take it that administrative law and procedure do exist, and that the stork did not bring them. Rather, they have been born of necessity and are still in the process of a very viable growth.

The words of $\mathrm{Mr}$. James $\dot{\mathrm{M}}$. Landis in his recent report on regulatory agencies to President-elect Kennedy are deserving of careful attention in Canada today:

Administrative procedures and practices have been a constant concern of the agencies themselves, the Courts, the bar and scholars for a long time antedating World War II. Pleas for flexibility in these procedures characterized the situation in the early 1930's. Application of even lax rules of evidence to administrative proceedings, particularly where they were being conducted by laymen, was thought undesirable. Comingling of the prosecuting and adjudicating functions was deemed not only necessary but advisable.

A reaction to these tendencies set in during the latter part of that decade Records became unduly long, causing expense and delay. Procedures unchecked by basic requirements other than loose concepts of due process varied from agency to agency bringing a sense of confusion to the entire administrative process. The combination of the functions of prosecutor and judge, especially in the hands of laymen, developed a belief that elements of faimess were too frequently absent ...

No single mind and no group of minds can in any short period of time grapple with all the implications of administrative procedure and bring forth a reasonably definitive code. This is a problem which has to be tackled piece by piece and year by year by men who have a continuing concern with its everchanging phases. No Hoover Commission or advisory committee established other than on a continuing basic can hope to evolve those procedures that should govern the many problems that the various regulatory agencies face. 58

58 Congressional Record, 87th Congress, 1st Sesston, Vol. 107, p. 17848 et seq. And see, U.S. News \& World Report, Jan. 9, 1961, p. 47 for a commentary thereon. 